\title{
Discursos y prácticas alrededor de la muerte. Reflexiones al hilo de 40 años de historiografía moderna en España
}

Discourses and practices around death. Reflections about 40 years of modern historiography in Spain

M. ${ }^{a}$ José de la Pascua

Universidad de Cádiz

CESXVIII, núm. 27 (2017), págs. 167-194 DOI: https://doi.org/10.17811/cesxviii.27.2017.167-194

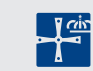




\section{RESUMEN}

En este estudio se realiza un estado de la cuestión de la producción española sobre la historia de la muerte reflexionando acerca de sus modelos historiográficos y metodológicos, la orientación de sus objetivos y su ubicación en un eje histórico básico: las coordenadas tiempo y espacio. Más que un recorrido exhaustivo por autores y trabajos que pudiera sugerir un tema agotado, se plantea la necesidad de incorporar la perspectiva individual en el análisis de la vivencia histórica de la muerte y la utilización integral de la fuente testamentaria valorando su condición de documento personal, cuya inclusión permitiría una aproximación al tema más compleja y matizada.

Palabras clave

Actitudes y discursos ante la muerte, historia de la muerte, siglos XVI, XVII y XVIII, historiografía española, historia de las mentalidades, historia moderna.

\section{AbSTRACT}

In this study I discuss the matter of Spanish works about the history of death, reflecting on its historiographies and methodological models, the orientation of its aims and its location on a basic historical axis: the time-space axis. More than an exhaustive study of authors and works that might lead one to think about an over discussed topic, I bring to attention the need to incorporate individual perspective in the analysis of the experience of death and the integral use of the testamentary source, acknowledging its condition as a personal document, the recognition of which allows an approach to a most complex and nuanced subject.

Key Words

Attitudes and Discourses to Death; History of Death; XVI, XVII and XVIII Centuries; Spanish Historiographic; Cultural History; Early Modern History.

Recibido: 25 de junio de 2017. Aceptado: 20 de julio de 2017. 
El modelo historiográfico analista de historia económico-social, triunfante en las décadas 50 y 60 del pasado siglo, tuvo un largo epílogo en las décadas finales del xx en el estudio del «tercer nivel» lo que por entonces se denominó la historia de las mentalidades. En la lógica de una representación de la vida social marcadamente estructuralista del que era deudor, lo simbólico venía a completar el espacio social incorporando al estudio de lo socioeconómico el mundo de las representaciones y a un tiempo histórico claramente dominado por los ciclos y el ritmo de la economía la más larga de las duraciones: la temporalidad de lo mental. Para aquellos que nos habíamos iniciado en el oficio de historiador de la mano de las nociones de la economía y, en todo caso, de una historia social que se revelaba como un apéndice de lo económico, paradigma triunfante en la práctica historiográfica occidental entre los años 30 y finales de los sesenta del siglo xx, el descubrimiento de un nuevo territorio que en vez de articularse en torno a la vieja historia de las ideas — de la cultura sabia, las creencias religiosas o las representaciones artísticas más excelentes-, se alineaba alrededor de una noción más antropológica de cultura vinculada a lo "psicológico colectivo», a los hábitos y costumbres o a los ritmos vitales ancestrales, constituyó un revulsivo. Uno de los temas que se abrió paso con potencia fue el de las actitudes ante la muerte, de la mano de esta noción de cultura pero inmerso a la vez, desde un primer momento, en una historia que se apoyaba en la sociología religiosa que venía reivindicando un acercamiento diferente a la religión ${ }^{1}$. En este sentido los análisis desde distintos temas de algunos historiadores y antropólogos (Jean Delumeau ${ }^{2}$, Emmanuel Le Roy Ladurie ${ }^{3}$, Robert Muchembled ${ }^{4}$, Carlo Ginzburg ${ }^{5}$ o Julio Caro

1 Los historiadores que iniciaron la historia de las mentalidades en los años 20 y 30 (Marc BLOCH y Lucien Febvre) venían orientados por la sociología de Émile Durкheim (Formas elementales de la vida religiosa, 1912) que intentaba explicar tanto la vida religiosa como sus funciones en la vida social al margen de la trascendencia, y desde una disciplina que aspiraba a hacer ciencia. Su idea de conciencia colectiva como vida psíquica y el concepto de «utillaje mental» como conjunto de recursos que permiten interpretar la realidad exterior se abrió paso en los estudios pioneros que fueron señalando el camino.

2 Jean Delumeau, El catolicismo de Lutero a Voltaire, Barcelona, Labor, 1973.

3 Emmanuelle Le Roy Ladurie, Montaillou, aldea occitana de 1294 a 1324, Madrid, Taurus Ediciones, 1981 (edición original de 1975).

4 Robert Muchembled, Culture populaire et culture des élites dans le France moderne (Xve-XVIIIe siècle), Paris, Flammarion, 1978.

5 Carlo Ginzburg, I Benandanti, Turín, Einaudi, 1966. 
Baroja $\left.\mathrm{a}^{6}\right)$, plantearon la necesidad de un proyecto de estudio de lo religioso y de las creencias incardinado en las prácticas sociales y culturales. A pesar de estas influencias (de la antropología cultural y de la sociología religiosa) el modelo de estudio histórico de las actitudes ante la muerte se forjó en el debate sobre el cambio o, más precisamente, sobre las temporalidades y la discontinuidad de la representación de la muerte y las actitudes ante ella. Tres autores pioneros en su análisis colocaron el énfasis sobre esta discontinuidad.

Philippe Ariès, atento a la llamada de atención de algunos contemporáneos — sociólogos como Geoffrey Gorer, filósofos como Edgar Morin, o desde el campo de la literatura Evelyn Waugh o Jessica Mitfford—que habían destacado por sus reflexiones críticas acerca de los cambios en las formas de afrontar la muerte en las sociedades capitalistas contemporáneas ${ }^{7}$, publicaba en 1967 dos primeros ensayos, recogidos posteriormente en un libro ${ }^{8}$, donde reunía una serie de conclusiones a las que estaba llegando en un trabajo aún no terminado. Asumiendo lo paradójico de publicar las conclusiones antes que el libro, Ariès señalaba que este tema que el venía abordando desde hacía 15 años ante la indiferencia general, en aquel momento agitaba a la opinión pública por lo que no había podido resistirse a la tentación de publicar algunos avances de su trabajo. Además de esa agitación, mediada la década de los 70, por un sujeto - la muerte- que, en general y salvo casos concretos (Johan Huizinga ${ }^{9}$, Emile Mâle $^{10}$, Erwin Panofsky ${ }^{11}$, Alberto Tenenti ${ }^{12}$ ), permanecía ajeno al interés de estudiosos y público en general, Ariès anticipaba la naturaleza de su inquietud como historiador. Desde su línea de investigación sobre el origen del modelo sentimental de familia, su interés se había deslizado hacia las costumbres funerarias y los sentimientos que expresaban algunos de esos ritos, concretamente el culto a los muertos y las visitas periódicas a las tumbas. Incluso una rápida

6 Julio Caro Baroja, Las brujas y su mundo, Madrid, Alianza Editorial, 1966.

M. a José de La PAScua SÁnchez, «Historiar la muerte: la producción española entre los años 1975 y 2000», en Miguel Rodríguez Cancho (coord.), Historia y perspectivas de investigación. Estudios en memoria del profesor Ángel Rodríguez Sánchez, Badajoz, Editora Regional de Extremadura, 2002, págs. 315-320, cita en pág. 315.

8 Philippe Ariès, Essais sus l'histoire de la mort en Occident du Moyen Age à nos jours, Paris, Éditions du Seuil, 1975. Esta edición francesa había sido precedida por una edición inglesa publicada por la Universidad Johns Hopkins en 1974.

9 Johan Huzzinga, El otoño de la Edad media, Madrid, Alianza Editorial, 1978 (edición original de 1919).

10 Emile MÂLE, El arte religioso de la Contrarreforma: Estudios sobre la iconografía del final del siglo XVI y de los siglos XVII y XVIII, Paris, Armand Colin, 1966 (edición original de 1932).

11 Erwin PANOFsky, Tomb Sculpture. Four lectures on its changing aspects from Ancien Egypt to Bernini, New York, Abrams, 1992 (edición original de 1962).

12 Alberto Tenenti, Il senso della morte e l'amore della vita nel Rinascimento. Francia e Italia, Turín, Einaudi, 1982 (edición original de 1957). 
mirada sobre el tema de la sepultura adelantaba, en palabras de Philippe Ariès, la naturaleza temporal de las actitudes sociales ante la muerte y algunos cambios significativos que podían precisarse con el estudio de otros aspectos: representaciones del más allá en la escatología cristiana o preparación del cadáver, representación del cadáver, entre otros. A partir de ellos, Ariès establecía una clara orientación de la diacronía en el modelo de muerte en Occidente que iba desde la «muerte domesticada» tradicional ${ }^{13}$, a la «muerte de sí» ${ }^{14}$. Esta última versión, según el autor, se había abierto paso en la segunda Edad Media y se caracterizaba por un sentido dramático y personal de la muerte que acabó con la tradicional familiaridad del hombre ante su destino final. A partir del siglo XVIII, el modelo de muerte propia, según Ariès, era sustituido por una actitud que ponía el énfasis sobre la «muerte del otro» ${ }^{15}$, la muerte del amado. Modelo que, a su vez, precedía a la revolución en las actitudes ante la muerte que se imponía en la sociedad occidental capitalista. La «muerte prohibida» ${ }^{16}$ se había abierto paso en el mundo industrializado donde los momentos finales eran paulatinamente arrancados de los hogares y la muerte quedaba replegada en los hospitales, evolución que iniciada en América del Norte se había precipitado, entre 1930 y 1950, en otros países de la Europa noroccidental donde alrededor de esta muerte «no consciente», había surgido una industria destinada a esconderla de la mirada de todos. Casi simultáneamente salía a la luz la investigación de otro historiador francés, Michel Vovelle presentada en 1971 como Tesis Doctoral y publicada en $1973{ }^{17}$. En este caso el interés por la muerte procedía del interés del autor por cartografiar y medir la descristianización en la Francia de la Revolución y del Directorio, así como la profundización en sus ritmos y causas a partir de una encuesta religiosa regresiva. En la Introducción de su obra Vovelle reconocía el papel inspirador que los estudios de sociología religiosa de Gabriel Le Bras habían tenido en su trabajo - en particular su Encuesta sobre la práctica religiosa católica en Francia de 1931 - y cómo la apuesta por una «historia religiosa serial» para el Antiguo Régimen, como venían proponiendo otros historiadores ${ }^{18}$ le parecía el método más válido para precisar los contornos y los contenidos de la «descristianización», proceso y concepto que venía sus-

13 ARIÈs, «La mort apprivoisée», Essais sur l'histoire de la mort, págs. 21-35.

14 Ariès, «La mort de soi», Essais sur l'histoire de la mort, págs. 37-50.

15 ARIÈs, «La mort de soi», Essais sur l'histoire de la mort, 51-65.

16 Ariès, «La mort interdite», Essais sur l'histoire de la mort, págs. 67-81. Este había sido uno de los primeros artículos que Ariès había dedicado al tema y fue publicado en 1967.

17 Michel Vovelle, Piété baroque et Déchristianisation. Les attitudes devant la mort en Provence au XVIIIe siècle, Paris, Plon, 1973.

18 Pierre Chaunu, «L'Histoire serielle. Bilan et perspectives», Revue Historique , 494 (1969), págs. $29-51$. 
citando un vivo debate entre los especialistas franceses. Unos 20.000 testamentos provenzales constituyeron la muestra sobre la que Michel Vovelle empleó técnicas estadísticas de la sociología contemporánea buscando los perfiles y ritmos de una práctica religiosa masiva alrededor de la muerte y en una sociedad próxima a la Revolución pero supuestamente cristiana. El siglo XvIII fue el marco temporal elegido y el testamento la fuente. Para Vovelle el testamento espiritual tal y como se había practicado en los siglos XVII y XVIII entregaba al historiador un sistema de prácticas codificadas alrededor de la muerte ${ }^{19}$. De su estudio se concluía un evidente cambio en el modelo de muerte barroca a lo largo del XvIII, cambios que aparecían generalizados en 1750, aunque en determinadas zonas se dibujaba una evolución precoz entre 1720 y 1730. La mutación implicaba a las prácticas habituales en torno a la muerte que iban perdiendo fuerza o desapareciendo. La petición de misas caía, como la elección de sepultura en la iglesia, también la demanda de exequias concurridas y el acompañamiento de cofradías. Todo ello testimoniaba una gran mutación de los comportamientos ante la muerte que venía acompañada por una creciente individualización de las actitudes y una atomización de las prácticas que se presentaban anteriormente mucho más monolíticas. El «desinterés» aparecía tempranamente entre las élites ilustradas y burguesas y Marsella, la gran ciudad de La Provenza, se evidenciaba como un excelente laboratorio para medir la precocidad de los cambios. Aún asumiendo la complejidad de las causas y considerando lo peligroso de una simplificación, Vovelle ofrecía un balance claro: para los provenzales del siglo XvIII la imagen de la muerte cambió y la red de gestos y ritos con los que se enfrentaba el último pasaje sufrieron una transformación profunda. ¿Podía hablarse de descristianización? Sí, según el historiador, si se tomaba como punto de partida un supuesto estado de cristianización completo en la edad clásica, de la que el testamento ofrecía un conjunto de gestos coherente ante la muerte. La convergencia en la desaparición del conjunto de ellos hacia 1720-1730, o algo más tarde dependiendo de los lugares, era señal una gran mutación de la sensibilidad colectiva ${ }^{20}$. Otros historiadores se habían incorporado a la historia de la muerte. François Lebrun interrogándose por los cambios que se operaban en la psicología colectiva con motivo de la presencia cíclica de la muerte catastrófica ${ }^{21}$, Pierre Chaunu que elegía Paris en los siglos XVI, XVII y XVIII para una encuesta similar a la de M. Vovelle a partir

\footnotetext{
19 Michel Vovelle, Piété baroque et Déchristianisation en Provence au XVIIIe siècle, Paris, Éditions du Seuil, 1978, pág. 25.

20 Vovelle, Piété baroque et Déchristianisation en Provence au XVIIIe siècle, págs. 265-326.

${ }^{21}$ François Lebrun, Les hommes et la mort en Anjou (aux XVIIe et XVIIIe siècles) : Essai de démographie et de psychologie historiques, Paris, Mouton, 1971.
} 
de millares de testamentos e inventarios post-mortem ${ }^{22}$ y Alain Croix analizando las estructuras demográficas, económicas y mentales en la Bretaña de los siglos XVI y XVII, donde la relativa escasez de testamentos era compensada con la incorporación de numerosos fuentes iconográficas ${ }^{23}$. Más allá de las conclusiones de estas investigaciones pioneras que, desde luego, orientarán el posterior debate, la discusión sobre la metodología de análisis tendrá un protagonismo indudable. Como apuntaba en páginas anteriores, la iniciativa novedosa de una «encuesta religiosa regresiva» propuesta por Vovelle a partir del estudio de series de testamentos fue leída a menudo en términos de dominio y/o exclusión de otro tipo de fuentes o tratamiento metodológico, por ejemplo, de la metodología más cualitativa presente en Philippe Ariès. Sin embargo, no era exactamente así. El propio Ariès no veía que sus trabajos fueran tan diferentes a los de su amigo Vovelle. Él mismo había recopilado una serie de testamentos a fin de analizar la actitud frente a la sepultura en la época clásica, con sondeos en los registros parisinos desde los siglos XVI al XIX. Para Ariès había dos modos de aproximarse a las representaciones de la muerte. Uno era el análisis cuantitativo de series documentales homogéneas y el otro la aproximación, más intuitiva y subjetiva, también más global, a una masa heteróclita de documentos, buscando con ello la expresión inconsciente de una sensibilidad colectiva. Este último método resultaba sospechoso porque, según el autor, utilizaba materiales nobles y de calidad estética que, en la consideración general, eran cauce de expresión de una élite. En realidad, concluía, cualquier pensamiento teológico, artístico, literario o que pareciera surgir de una inspiración individual no puede más que encontrar lenguaje y estilo en la forma del sentir general y común de su época. En la proximidad a otras formulaciones comunes ese testimonio literario revelaba al historiador el denominador común de un tiempo y en las diferencias con aquellas anunciaba proféticamente los cambios futuros ${ }^{24}$. Por su parte, el historiador que aparecía como abanderado del tratamiento cuantitativo y de una historia serial de las sensibilidades religiosas a través del análisis de series de testamentos, de altares de ánimas ${ }^{25}$ o de epitafios ${ }^{26}$ insistía en medir los gestos de la práctica; pesar y contar para hallar tanto las huellas o indicadores de com-

22 Pierre Chaunu, «Mourir à Paris (xvie, xvile, xviIIe siècles)», Annales ESC, 1 (1976), págs. 20-50 y La mort à Paris (16. ${ }^{e}, 17 .^{e}, 18 .^{e}$ siècles), Paris, Fayard, 1978.

23 Alain Croix, La Bretagne aux 16.e et 17. e siècles. La vie, la mort, la foi, Paris, Maloine, 1981, 2 vols.

24 ARIÈs, Essais sur l'histoire de la mort en Occident, págs. 13-17.

25 Gaby et Michel Vovelle, Vision de la mort et de l'au-delà en Provence d'après les autels des aimés du Purgatoire, Xve- xxe siècles, Paris, Armand Colin, 1970.

26 Michel Vovelle, «A Century and One-Half of American Epitaphs (1660-1813): Toward the Study of Collective Attitudes about Death», Comparative Studies in Society and History, vol. 22-4 (1980), págs. 534-547. 
portamientos comunes y confesiones indiscretas como de su evolución en la longue durée ${ }^{27}$. Para Vovelle el cambio de enfoque en el análisis de documentos que implicaba un estudio serial revelaba densidades y temporalidades en los gestos muy esclarecedoras. Pero aún más importante le parecía la potencialidad del enfoque serial para ir, más allá del discurso y de la religiosidad de las élites, al conocimiento de las masas anónimas que no habían podido acceder al lujo de una expresión individual literaria. Consciente, no obstante, de los límites de este tipo de investigación (pobreza de las fuentes masivas, carácter estereotipado y repetitivo de la información), la tarea más ardua a la que se enfrentaba el historiador en estos casos, según Vovelle, era la interpretación de los silencios. ¿Qué conclusión sacar cuando la fuente se vuelve muda como sucede con los testamentos provenzales a partir de 1750? Por otra parte, el mismo no desdeñaba el recurso a las otras fuentes, aquellas que eran tradicionalmente objeto de un tratamiento metodológico cualitativo, aunque siempre desde el objetivo de rastrear comportamientos, actitudes y gestos colectivos. Es lo que hacía Ariès, según Vovelle explicaba, manejando referencias múltiples tomadas de variados registros arqueológicos, iconográficos o literarios, y privilegiando los escritos pequeños — diarios, memorias, relatos anónimos-, los menos literarios, frente la gran literatura ${ }^{28}$, como él mismo había hecho ${ }^{29}$. A pesar de este consenso sobre la necesidad de no descartar ningún tipo de fuente ni de aproximación analítica al tema, el objetivo de acceder a los valores medios impregnó la mayoría de los estudios realizados sobre representaciones y actitudes ante la muerte, también los realizados sobre los discursos sobre la muerte ${ }^{30}$.

Pero si había algo en lo que discrepaban estos dos historiadores pioneros en la historia de la muerte era una diferente opinión sobre el sentido de los silencios. En los testamentos de la segunda mitad del siglo XVIII el peso de los silencios desplazaba al detalle y la minuciosidad con el que se disponía todo lo concerniente al entierro, al funeral y a las mandas piadosas un siglo antes. Vovelle no había dudado en interpretar la desbandada como indicio claro de desapego a un modelo de muerte muy jerarquizado, como lo era la sociedad

27 Michel Vovelte, Ideologías y mentalidades, Barcelona, Ariel, 1985, págs. 25-42 (edición original de 1982).

28 Vovelle, Ideologías y mentalidades, págs. 37-42.

29 Michel VovelLe, Mourir autrefois. Attitudes collectives devant la mort aux XVIIe et XVIIIe siècles, Paris, Gallimard-Julliard, 1974.

30 El estudio sobre las «artes de morir» en Francia en la época clásica de Daniel Roche («La mémoire de la mort», Annales ESC, 1 (1976), págs. 76-119), donde se identificaba un doble discurso sobre la muerte, uno dirigido a las masas y otro a los intelectuales, o el de Roger CHARTiER, contextualizado en una época anterior («Les arts de mourir, 1450-1600», Annales ESC, 1 (1976), págs. 51-75) en el que se analizaban distintos campos temáticos asociados a la idea de la muerte. 
del Antiguo Régimen y como muestra de una mutación en los comportamientos colectivos. La convergencia en la cronología del vaciado de las disposiciones alrededor de la muerte — petición de hábito, designación del lugar de sepultura, elección de funeral y acompañamiento, petición de misas y fundaciones y declive de las cofradías - que eran habituales en el testamento barroco señalaba para Vovelle un cambio profundo. Así, en su interpretación, del mismo modo que la unanimidad en la presencia de todos estos gestos en el testamento clásico servía para hablar de «cristianización», su desaparición — desaparición masiva y convergente - bien podía autorizarnos a hablar de «descristianización». A pesar de que fue el calificativo con el que Vovelle llamó al proceso, lo más asumido por la comunidad historiográfica para entrar en el debate, la explicación del proceso por el historiador francés era mucho más compleja. Tres lecturassignificados que Vovelle adelantaba sobre el cambio en el modelo de muerte que proyectaban los testamentos provenzales de la segunda mitad del XVIII eran muy significativas. Vovelle interpretaba el silencio de los testamentos como síntoma de una individualización de las actitudes y una atomización de prácticas que antaño aparecían más monolíticas. Por otra parte, aunque el silencio era masivo se percibía que comenzaba en las élites, si bien no homogéneamente, ya que la deserción era indiscutible entre la burguesía mientras los testamentos nobiliarios presentaban signos de mayor inmovilismo. Había otro dimorfismo social relevante, esta vez de carácter socio-sexual, en la ratio por sexos se hacía evidente una mayor presencia de testamentos femeninos por lo que Vovelle concluía que el testamento se feminizaba. ¿Podía interpretarse como una mayor independencia de las mujeres en la práctica? Una tercera lectura sobre los cambios en los testamentos provenzales era planteada por Vovelle como un fortalecimiento de lo inherente a la vida terrena frente a la trascendencia: un mayor interés por el cuerpo físico acompañaba al desinterés por aquellos gestos comunes en el modelo de muerte barroca que remitían a valores como resurrección/juicio final/salvación ${ }^{31}$. Para Philippe Ariès, los cambios en el estilo y el tono de los testamentos a mediados del XVIII tenían relación con un moderno sentimiento de familia. Si el testamento desde la Edad Media aparece con una función religiosa, casi sacramental y se dedica en su mayor parte ad pias causas por parte de un testador que, en lo que respecta a la salvación de su alma, no quiere dejar nada al azar, a lo largo del XVIII se evidencia que esta función cambia. Las cláusulas religiosas son despachadas con frases convencionales o desaparecen y el testamento queda como un acto jurídico privado destinado a la repartición de los bienes del difunto. El moribundo ya no se siente solo ante su destino sino

\footnotetext{
31 Vovelle, Piété baroque et Déchristianisation en Provence, págs. 314-312.
} 
rodeado de los suyos a quienes convierte en discretos albaceas y comunica sus deseos sobre su funeral y entierro. Lo que realmente ha cambiado, para Ariès, era el sentimiento familiar ${ }^{32}$.

La polémica, sin duda, animó las investigaciones sobre el siglo XVIII. Pero, medido y debatido un sistema de gestos alrededor de la muerte situando el énfasis en el momento de su desaparición, se hacía evidente que al tiempo que interpretar los silencios en las cláusulas testamentarias era preciso medir también las presencias y la cronología de su desarrollo. A comienzos de los 80, el análisis del proceso de domesticación cristiana de la muerte a lo largo de la Baja Edad Media, de cristianización o clericalización como se denominó, tuvo un historiador destacado. Jacques Chiffoleau también se decantaba por la fuente testamentaria —unos 6.000 testamentos_ ${ }^{33}$. La muestra de ellos procedente de Avignon en la época de la gran depresión entre 1320 y 1480 , era utilizada para estudiar las actitudes ante la muerte, con el ánimo no tanto de hacer una nueva contribución a la historia de la muerte, sino porque el autor asumía la idea de la muerte como reveladora de una función específica de la religión en la vida social ${ }^{34}$. Según el autor, hacia 1340 el miedo al Juicio Final pareció reconducirse al miedo a morir ab-intestato, y el testamento en sus distintas disposiciones comenzó a mostrar los signos evidentes de unas formas nuevas que revelaban una transformación de las mentalidades. Los testamentos se alargaron, haciéndose más retóricos, el número de misas solicitado por el testador aumentó significativamente, al tiempo que la sepultura en la Iglesia fue sustituyendo a la sepultura en el cementerio y el cortejo fúnebre se transformó en una procesión con antorchas y acompañamiento de pobres y clérigos. Había hecho su aparición «la muerte de sí», descubrimiento inquietante, contemporáneo al desarrollo de la práctica testamentaria entre finales del siglo XIII y comienzos del XIV en un contexto cultural de cuestionamiento de las viejas solidaridades familiares y los tradicionales lazos parentales a causa del desarrollo económico y urbano. Este cambio que había sido puesto en relación a menudo con la Peste y las crisis de mortalidad de la Baja Edad Media fue interpretado por Chiffoleau como respuesta a una crisis en las estructuras familiares favorecida por la nueva moral que acompañaba al desarrollo económico, comercial y urbano que había hecho su aparición y

32 ARIÈs, «Du sentiment moderne de la famille dans les testaments et les tombeaux», Essais sur l'histoire de la mort, págs. 143-153.

33 Jacques Chiffoleau, La comptabilité de l'Au-Delà. Les hommes, la mort et la religion dans la région d’Avignon à la fin du Moyen Age (vers 1320-vers 1480), Rome, Ecole Française de Rome, 1980, pág. 179.

34 Jacques Chiffoleau, «Perché cambia la morte nella regione di Avignone alla fine del Medioevo», Quaderni Storici, 50 (1982), págs. 449-465. 
que la Iglesia estaba empeñada en dominar ${ }^{35}$. Para el autor, aunque desde la Antigüedad tardía, la muerte era el centro de un proceso de «cristianización» y se constataba un esfuerzo constante de los clérigos por controlar este momento esencial, en plena expansión del mundo comercial y urbano entre los siglos XII y XIII, de desajuste del orden feudal y la quiebra de las tradicionales obediencias, sumisiones y solidaridades parentelares, los clérigos redoblaron el esfuerzo por controlar estos cambios a través del miedo a la muerte. El control sobre la muerte se reforzará. En este contexto, el testamento traduce una cierta liberación del individuo frente al grupo; seguirá asegurando la reproducción de la vida familiar, pero a cambio da a la muerte del individuo, a la muerte de «sí», un lugar que no había tenido antes ${ }^{36}$. La clericalización de la muerte, modelo que podríamos extender entre los siglos XIV y XVIII sería, en la interpretación de Chiffoleau, síntoma y evidencia de un modelo de representación de la muerte propia.

La temporalidad/temporalidades en las representaciones de la muerte, tal y como nos legaban los estudios de los historiadores franceses no se ceñían exclusivamente al tiempo largo, aquel que abarcaba desde la difusión del modelo de muerte clericalizada, con el momento de apogeo-crisis en la época de la Contrarreforma hasta el de la descomposición del modelo en el Siglo de las Luces, había otros tiempos. Tiempos/espacios podría decirse porque en el seno de esa representación de la muerte de la que los testamentos daban cuenta, la organización del entierro y de la pompa funeral proporcionaba otro sentido temporal: los tiempos y ritmos de una muerte pública. El testamento era parco en noticias y disposiciones sobre la vivencia de la muerte en el espacio privado, sobre lo que ocurría en la cama del moribundo, incluso sobre los primeros momentos de duelo y vela. Por el contrario, las disposiciones sobre la sepultura, la organización de las exequias y del acompañamiento constituían la piedra angular del dispositivo piadoso. El análisis de ese tiempo de la muerte en el espacio público que era, sobre todo, representación social, arrojaba como conclusión evidente un modelo de muerte barroca que si por algo destacaba era por su carácter jerarquizado.

Con esta herencia y con los referentes indiscutibles de los historiadores que habían iniciado el estudio de las actitudes ante la muerte (F. Lebrun, M. Vovelle, Ph. Ariès, P. Chaunu), pero también desde aquellos que venían postulando una aproximación al «tiempo de vivir»(Bartolomé Bennassar ${ }^{37}$ ), los

\footnotetext{
35 Chiffoleau, La comptabilité de l'Au-Delà, págs. 77-89.

36 Chiffoleau, La comptabilité de l'Au-Delà, pág. 89.

37 Bartolomé Bennassar, Los españoles. Actitudes y mentalidad, Barcelona, Argos, 1978 (edición original de 1975)
} 
primeros ecos en la historiografía española aparecieron en un trabajo presentado en las Primeras Jornadas de Metodología Aplicada a la Ciencia Histórica (Santiago de Compostela, 1975 ${ }^{38}$ ) y en una sección que se le dedicó al tema en el II Coloquio de Metodología Aplicada a la Ciencia Histórica (Santiago de Compostela, $1983^{39}$ ), ambos organizados bajo el impulso del profesor Antonio Eiras que convocaba a los historiadores españoles a la utilización de los protocolos notariales como fuente fundamental para la Historia. La cultura material, la cultura lectora y la cultura religiosa se configuraban, al hilo de las aportaciones en ambas reuniones, como territorios novedosos y activos de la historia de las mentalidades. El estudio de la muerte, en distintos periodos y zonas de la Península, se hizo eco de los enfoques y los debates suscitados por los trabajos de los historiadores franceses. Estos plantearon especialmente las posibilidades del testamento como fuente y la problemática de su representatividad. Una noción de mentalidad que compartían historiadores de referencia ${ }^{40}$ y que incidía sobre su traducción en hábitos y conductas medias había desembocado bien pronto en el debate sobre las fuentes susceptibles de seriación. La utilización de los protocolos notariales como fuente esencial para la historia social, cre-

38 Baudilio Barreiro MaLlón, «El sentido religioso del hombre ante la muerte en el Antiguo Régimen. Un estudio sobre archivos parroquiales y testamentos notariales», en VV. AA., Actas de las I Jornadas de Metodología Aplicada de las Ciencias Históricas (1973), Santiago de Compostela, Secretariado de Publicaciones de la Universidad de Santiago, 1975, vol. V, págs. 181-197.

39 Baudilio Barreiro Mallón, «La nobleza asturiana ante la vida y la muerte» en Antonio Eiras Roel (coord.), La documentación notarial y la Historia. Actas del II Coloquio de Metodología Histórica Aplicada, Santiago de Compostela, Servicio de Publicaciones de la Universidad de Santiago, 1984, vol. II, págs. 27-65; Ricardo García Cárcel, «La muerte en la Barcelona del Antiguo Régimen. Aproximación metodológica», en Antonio Eiras Roel (coord.), La documentación notarial y la Historia, vol. II, págs. 115-124; Pere Molas Ribalta, «Religiosidad y cultura en Mataró. Nobles y comerciantes en el siglo XVIII», en Antonio Eiras Roel (coord.), La documentación notarial y la Historia, vol. II, págs. 94-114 y Domingo GonzáLEz Lopo, «La actitud ante la muerte en la Galicia occidental de los siglos XVII y XVIII», en Antonio Eiras Roel (coord.), La documentación notarial y la Historia., vol. II, págs.125-138.

40 En estos años, en los Terceros Annales, se trabaja la mentalidad como visión del mundo y con un enfoque estructural. Se define la historia de las mentalidades como historia de los sistemas del mundo (Georges Duby, «Histoire des mentalités», L’histoire et ses méthodes, Paris, Gallimard, 1961, pág. 964. Philippe Ariťs afirma que se trata de estudiar las conductas en las que se plasman los sistemas de valores sociales y los modos de organización colectiva («L'Histoire des mentalités», La nouvelle histoire, Paris, CEPL, 1978). Bartolomé Bennassar la identifica con el objetivo de conocer y comprender la actitud, consciente o inconsciente, del mayor número de gente posible en el pasado, frente a determinados problemas y contando los historiadores con la incapacidad de esta gente de expresarse de modo claro sobre el particular («Historia de las mentalidades», La historiografía en Occidente desde 1945, Navarra, Universidad de Navarra, 1985, pág. 213). Para Jacques Le GofF, las mentalidades son un alma colectiva; se nutren del mundo de las ideas pero abrevan ellas mismas en el mundo de las profundidades. Estudiar el mundo de las mentalidades es ante todo estudiar el instrumental mental («Tiempos breves, tiempos largos. Perspectivas de investigación», Lo maravilloso y lo cotidiano en el Occidente medieval, México, Gedisa, 1985, pág. 158). Para VovelLe se trataba de analizar las actitudes, comportamientos y representaciones colectivas inconscientes más que situarse al nivel del pensamiento claro (Ideologías y mentalidades, pág. 12). 
ciente desde los años 50, había aportado ya un conocimiento de los documentos notariales y del testamento en particular. En el Coloquio de Estrasburgo de 1978, Jean-Paul Poisson ${ }^{41}$, Jean Meyer ${ }^{42}$, y el propio Vovelle ${ }^{43}$ habían planteado cuestiones básicas acerca de la crítica de la fuente testamentaria. Se sabía que el proceso de expansión del testamento nuncupativo o testamento abierto, desaparecido prácticamente en Occidente entre los siglos VIII y XII y reaparecido con sus características clásicas (nuncupatio, presencia de testigos e institución de heredero) entre los siglos XIII y XIV, había venido acompañada de su democratización. En definitiva, de la difusión entre amplias capas de la población facilitada por su condición de herramienta para preparar la buena muerte, una especie de «sacramental». También se había observado que su expansión había sido más rápida en el mundo urbano, aunque su representatividad variaba dependiendo de las zonas. Alta en aquellas de tradición del derecho romano, dependía también de las distintas tradiciones de derecho sucesorio, del régimen de bienes dominante en el matrimonio, de la mayor libertad o no, por tanto, de las mujeres para administrar sus bienes y, en alguna medida, del propio hábito de los habitantes de acudir al notario para llevar a cabo distintas actividades. En líneas generales y para la Europa occidental y católica, entre finales del XIII y finales del XVIII, se configuraron dos espacios en lo que respecta a la práctica testamentaria. Una zona norte donde esta era escasa y una Europa sur en la que el testamento, en el apogeo de la práctica, concernía a gran parte de los adultos de sexo masculino y a una mayoría de sexo femenino. La evolución del mismo señalaba la incorporación creciente a la práctica de los sectores medios y bajos de la sociedad y a un número creciente de mujeres ${ }^{44}$. En las primeras investigaciones españolas Claude Larquiè consideraba el testamento como representativo de todos los medios sociales del Madrid del XVII, y de su difusión hasta en los medios más modestos, con la sola excepción de los que no tenían absolutamente nada, llamando la atención sobre las declaraciones testamentarias de pobreza ${ }^{45}$, mientras B. Barreiro concluía sobre una representatividad relativamente escasa

${ }^{41}$ Jean-Paul Porsson, «Histoire et actes notariés. Problématique et methodologie», en Bernard Vogler (ed.), Les Actes Notariés. Source de l'histoire sociale XVIe-XIXe siècles. Actes du Colloque de Strasbourg (1978), Strasbourg, Librairie Istra, 1979, págs. 17-30.

42 Jean Meyer, «La documentation notariale en Bretagne à l'époque moderne», en Bernard Vogler (ed.), Les Actes Notariés, págs. 31-46.

43 Michel Vovelle, «Un préalable à toute histoire sérielle: la représentativité sociale du testament (xıve- Xıxe siècle)», págs. 257-278.

44 VovelLe, «Un préalable à toute histoire sérielle: la représentativité sociale du testament (xIVe- XIXe siècle)», pág. 257.

45 Claude Larquite, «Une aprocheé cuantitative de la pauvreté: les madrilènes et la mort au xvIIe siècle», Annales de Démographie Historique, 15 (1978), págs. 175-196. 
del testamento a partir del cotejo entre testadores y difuntos en Asturias ${ }^{46}$. En cualquier caso, los resultados de Barreiro para Asturias hablaban de un 30 por ciento de difuntos con testamento, porcentaje que confirmaban las investigaciones de los primeros años ochenta en Extremadura donde se había formado un grupo de investigación sobre historia de las mentalidades dirigido por el profesor Ángel Rodríguez Sánchez ${ }^{47}$. También en Andalucía se concluían, mediados los ochenta, investigaciones en curso sobre Cádiz ${ }^{48}$, Málaga ${ }^{49}$, Córdoba ${ }^{50}$ y Sevilla ${ }^{51}$. El Congreso de Religiosidad Popular celebrado en Sevilla en 1987, que reunió a un buen número de historiadores españoles con esta línea de investigación común ${ }^{52}$, evidenció la fortaleza de estos trabajos en Andalucía donde se habían concluido ya dos tesis doctorales sobre el tema ${ }^{53}$ e iniciado otras tres que se concluirían en los $90^{54}$, posteriormente se incorporaría una investigación sobre Granada ${ }^{55}$. El Congreso de Zaragoza sobre Muerte, religiosidad y Cultura $(1989)^{56}$ fue un buen barómetro para comprobar la extensión de la historia de la muerte en el suelo peninsular (Galicia, cornisa cantábrica, Meseta norte, Andalucía, Cataluña y Levante). La Galicia noroccidental tenía una investigación

46 Barreiro Mallón, «El sentido religioso del hombre», págs. 181-197 y Barreiro Mallón, «La nobleza asturiana ante a vida y la muerte», págs. 27-65.

47 Ángel Rodríguez SÁnchez, «Morir en Extremadura. Una primera aproximación», Norba, 1 (1980), págs. 279-297 y Ángel Rodríguez SÁnchez, Morir en Extremadura. La muerte en la horca a fines del Antiguo Régimen, 1792-1909, Cáceres, El Brocense, 1980; Rosa M. ${ }^{a}$ Valverde, La muerte en cuatro núcleos cacereños durante el siglo XVII, Memoria de Licenciatura defendida en la Universidad de Extremadura en 1981; e Isabel Testón Núñez, Estructuras mentales y vida cotidiana en la sociedad extremeña durante el siglo XVII, Tesis Doctoral defendida en la Universidad de Extremadura en 1982.

48 M. José de la Pascua Sánchez, Actitudes ante la muerte en el Cádiz de la primera mitad del siglo XVIII, Cádiz, Diputación Provincial de Cádiz, 1984.

49 Marion Reder GADOw, Morir en Málaga. Testamentos malagueños del siglo XVIII, Málaga, Diputación Provincial, 1985.

50 Soledad Gómez Navarro, El sentido de la muerte y la religiosidad a través de la documentación notarial cordobesa (1790-1814), Granada, Ilustre Colegio Notarial de Granada, 1985.

51 José A. Rivas Álvarez, Miedo y piedad, testamentos sevillanos del siglo XVIII, Sevilla, Diputación Provincial de Sevilla, 1986.

52 León C. Álvarez, M. Jesús Buxó, Salvador Rodríguez (coords.), La religiosidad popular II. Vida y muerte: La imaginación religiosa, Barcelona, Anthropos, 1989.

53 Reder Gadow, Morir en Málaga; y M. José de la Pascua Sánchez, Vivir la muerte en el Cádiz del Setecientos (1675-1801), Cádiz, Cátedra Adolfo de Castro / Municipal de Cultura del Ayuntamiento de Cádiz, 1989.

54 David González Cruz, Religiosidad y ritual de la muerte en la Huelva del Siglo de la Ilustración, Huelva, Diputación Provincial de Huelva, 1993, Soledad Gómez Navarro, La muerte en la provincia de Córdoba, Sevilla, Colegio Notarial de Sevilla, 1996 y Manuel José de Lara Ródenas, La muerte barroca. Ceremonia y sociabilidad funeral en Huelva durante el siglo XVII, Huelva, Universidad de Huelva, 1999.

55 Amalia García Pedraza, Actitudes ante la muerte en la Granada del siglo XVII, Granada Publicaciones de la Universidad, 2002.

56 Eliseo Serrano (ed.), Muerte, religiosidad y cultura popular, siglos XIII-XVIII, Zaragoza, Institución Fernando El Católico, 1994. 
en curso que daría su fruto maduro años más tarde ${ }^{57}$; Asturias ${ }^{58}$, Cantabria ${ }^{59}$, País Vasco $^{60}$, Valladolid ${ }^{61}$, Zamora $^{62}$, León $^{63}$, Salamanca ${ }^{64}$; Castilla-La Mancha ${ }^{65}$, Cataluña ${ }^{66}$, Valencia ${ }^{67}$, Castellón ${ }^{68}$ y, en general, el Levante peninsular también tenían ya investigaciones publicadas y en vías de realización ${ }^{69}$. Con este reco-

57 Domingo L. GonzÁlez Lopo, Los comportamientos religiosos en la Galicia del Barroco, Santiago de Compostela, Xunta de Galicia, 2002.

58 Roberto J. López Lopez, Oviedo: muerte y religiosidad en el siglo XVIII. Un estudio de las mentalidades colectivas, Oviedo, Servicio de Publicaciones del Principado de Oviedo, 1985 y Roberto J. LóPEz LoPEz, Comportamientos religiosos en Asturias durante el Antiguo Régimen, Gijón, Principado de Asturias / Silverio Cañada, 1989; José Antonio V Aquero Iglesias, Muerte e Ideología en la Asturias del siglo XIX, Madrid, Siglo XXI, 1991.

59 Ramón Maruri Villanueva, La burguesía mercantil santanderina, 1700-1850. (Cambio social y de mentalidad), Santander, Universidad de Cantabria, 1990, Cap. V. Recientemente se ha publicado un nuevo trabajo sobre la zona, Josué Fonseca Montes, Religión, muerte y sexualidad en los siglos XVI- XVIII: el caso de Cantabria, Santander, Universidad de Cantabria, 2014, en especial págs. 397-473.

60 Juan Madariaga Orbea, Actitudes ante la muerte en el Valle de Oñati durante los siglos XVIII y XIX. Leioa, Universidad del País Vasco, 1993 y Juan Madariaga Orbea, Una noble señora. Herrio Anderea. Actitudes ante la muerte en el País Vasco, siglos XVIII y XIX, Bilbao, Universidad del País Vasco, 1998.

61 Máximo García Fernández, Los castellanos y la muerte. Religiosidad y comportamientos colectivos en el Antiguo Régimen, Valladolid, Junta de Castilla y León, 1996.

${ }^{62}$ Francisco J. Lorenzo Pinar, Actitudes ante la muerte en Zamora en el siglo XVI: un estudio de mentalidades, Zamora, Instituto de estudios Zamoranos Florián Ocampo, 1984 y Francisco José Lorenzo Pinar, Muerte y ritual en la Edad Moderna (1500-1800), Salamanca, Universidad de Salamanca, 1991.

${ }_{63}$ Laureano López Rubio, La Bañeza y su tierra, 1650-1850. Un modelo de sociedad rural leonesa (los hombres, los recursos y los comportamientos sociales), León, Universidad de León, 1987, Cap. VI.

${ }^{64}$ Clara I. López, La nobleza salmantina ante la vida y la muerte (1476-1535), Salamanca, Diputación Provincial de Salamanca, 1991.

${ }_{65}$ Fernando Martínez GiL, Actitudes ante la muerte en el Toledo de los Austrias, Toledo, Ayuntamiento de Toledo, 1984, completado en un trabajo posterior: La muerte vivida: muerte y sociedad en Castilla durante la Baja Edad Media, Madrid, Diputación Provincial de Madrid, 1996.

${ }_{66}$ Olga López Miguel, Actituds col.lectives davant la mort $i$ discurs testamentari al Mataró del segle XVIII, Mataró, 1987; Lourdes Mateo Bretos, «Actitudes ante la muerte de la población de Sitges en los siglos XVI-XVII», en León C. Álvarez, M. Jesús Buxó, Salvador Rodríguez (coords.), La religiosidad popular, págs. 261-272; Diego Granado, «Les ultimes voluntats a una comunitat rural», L’Avenç, 78 (1985), págs. 68-71, y Andreu Domingo, «El discurs eclesiàstic sobre la mort: els sermons funeraris», L'Avenç, 78 (1985), págs. 72-75, entre otros.

67 Genaro Lamarca, «Los campesinos ante la muerte. Valencia, 1730-1860. Un estudio sobre el discurso testamentario», Anales Valentinos, 17 (1983), págs. 167-202 y Vicente LEón, El pensamiento de la muerte. Actitudes valencianas en el siglo XVIII, Tesis de Licenciatura, Universidad de Valencia, 1990.

68 Pere Saborit Badenes, Morir en el Alto Palencia. La religiosidad popular a través de los testamentos. Siglos XVII- XVIII, Segorbe, Ayuntamiento de Segorbe, 1991.

69 M. a José GARCía GASCón, «El ritual funerario a fines de la Edad media: una manifestación de religiosidad popular», en León C. Álvarez, M. Jesús Buxó, Salvador Rodríguez (coords.), La religiosidad popular, págs. 224-243, M. Isabel Macia Ferrandez, «Las pías fundaciones testamentarias en el siglo XVIII. Aproximación al caso de Orihuela (Alicante)», Anales de Historia Contemporánea 3 (1984), págs. 7-24; Anastasio Alemán Illán, «Actitudes colectivas ante la muerte en Murcia durante el siglo XVIII», Cuadernos de Historia Moderna y Contemporánea, 9 (1988), págs. 95-120, Ramón PeÑafiel, Testamento y buena muerte. Un estudio de mentalidades en la Murcia del siglo XVIII, Murcia, Academia Alfonso X El Sabio, 1987 y Amparo Bejarano Rubio, Los testamentos murcianos bajomedievales, Cartagena, Ayuntamiento de Cartagena, 1990. 
rrido, sin intención alguna de exhaustividad, solo se pretende evidenciar que a lo largo de la segunda década de los ochenta la historia de las actitudes ante la muerte se había afianzado en la historiografía española, con desigual resultado aunque con una clara inspiración en la obra de M. Vovelle. Esta se evidenciaba en la utilización general del testamento como fuente básica, aunque no se excluyeran generalmente muchas otras fuentes como actas de defunción, visitas pastorales, sermones, literatura religiosa y artes de preparación de la muerte, o iconografía. También en la decantación de gran parte de las investigaciones por el siglo XVIII y el mundo urbano y, sobre todo, por la incorporación del debate sobre la «descristianización». La mayoría de estas investigaciones concluían sobre una representatividad notable del testamento, que afectaba más o menos a un tercio de la población difunta adulta, aunque con fuertes diferencias zonales y casos de excepción en este panorama general (Sevilla, por ejemplo, ofrecía en el siglo XVIII, una baja representatividad de la fuente). También pudo establecerse que el testamento era más usual entre los habitantes de las zonas urbanas - aquí también había excepciones como la Galicia interior de los siglos XVII y XVIII- y que las mujeres estaban incorporadas a la práctica testamentaria. Esto estaba claro en Francia cuyo testamento, a lo largo del xvIII, se feminizaba (en La Provenza, Bretaña y París ${ }^{70}$ ). Por lo que se refería España, las mujeres estaban incorporadas a la práctica testamentaria ya en el siglo XVIII en la Galicia noroccidental, Oviedo, la Meseta norte (Zamora, León y Valladolid), en Extremadura ${ }^{71}$, Cataluña y Andalucía. En prácticamente todas estas zonas los testamentos femeninos se acercaban o superaban el 40\%. En este caso, Cádiz, mi área de observación, no era así; ciudad donde la población masculina superaba a la femenina debido a la presencia de una fuerte emigración, era la localidad que arrojaba uno de los valores más bajos con el 37\% de media para todo el $\mathrm{XVIII}^{72}$.

La mayoría de las investigaciones señalaban el carácter estereotipado del preámbulo religioso testamentario en el que no era difícil deducir la utilización de Formularios manejados por los notarios ni identificar la procedencia erudita y clerical de este discurso. Sin embargo, algunas investigaciones en

70 VovelLe, «Un préalable a toute histoire sérielle», pág. 274.

71 Antonio Sotelo LóPez, «La muerte en Badajoz durante el siglo xviII», en VV. AA., Congreso de Jóvenes historiadores y geógrafos, Madrid, Universidad Complutense, 1988 y Mercedes Santillana PÉrez, La vida: nacimiento, matrimonio y muerte en el partido de Cáceres en el siglo XVIII, Cáceres, Diputación Provincial de Cáceres, 1992, págs. 152-153.

72 Se puede seguir con detalle el tema de la práctica testamentaria femenina en M. José de la PAscuA SÁnchEz, «Desde la vida para la muerte: testamento barroco y religiosidad femenina», en Virginia Alfaro Bech y Lidia Taillefer de Haya (eds.), Nueva lectura de la Mujer. Crítica histórica, Málaga, Universidad de Málaga, 1995, págs. 185-224. 
las que se había realizado un estudio sistemático de las fórmulas se constató la presencia de cambios y modificaciones en el tiempo corto y la existencia de fórmulas singulares. Modificaciones y fórmulas singulares que, obviamente, se incorporaron en su momento a iniciativa del testador, señalando que el discurso testamentario sobre la muerte, en su versión de muerte cristiana, era parte viva del testamento y del modelo de muerte. También era significativo el paulatino adelgazamiento y empobrecimiento de estas fórmulas en los testamentos de Cádiz de la segunda mitad del siglo XVIII ${ }^{73}$ y en los de Tuy y Santiago de Compostela al filo del Ochocientos ${ }^{74}$. Sobre el contenido del dispositivo espiritual —elección de mortaja, sepultura, acompañamiento de entierro, petición de misas y otros legados piadosos-, el modelo jerarquizado de exequias con numeroso acompañamiento, la petición de sepultura en las iglesias y la demanda de misas por el alma, no había muchas diferencias zonales en lo sustancial, señal que el modelo estaba bien establecido. Los matices venían dados, básicamente, por la distinta capacidad económica de los testadores o mejor por la convergencia de estatus y bienes propios que determinaba las distancias entre unas exequias espléndidas y otras más humildes. Sin embargo, los cambios también llegaban a este dispositivo que, en algunas zonas, se empobrecía conforme avanzaba la segunda mitad del Setecientos señalando un cierto desinterés por la concreción de todos estos detalles en otros tiempos asumidos como necesarios para una buena muerte. En Galicia, entre 1791 y $1810^{75}$, en Barcelona ${ }^{76}$, en Murcia ${ }^{77}$, en Sevilla, hacia $1750^{78}$ o en la provincia de Cádiz se constataba la quiebra de un sistema de gestos en torno a la muerte, general en el siglo anterior. En Cádiz, por ejemplo, los testamentos tanto en el medio urbano (Cádiz y El Puerto de Santa María) como en el medio rural (Medina Sidonia y Alcalá de los Gazules) señalaban el periodo 1675-1801 como época de cambios. Se percibían, no obstante, ritmos diferentes y contrastes entre el mundo urbano y rural: en aquel se iniciaba antes el desgaste del modelo, identificable ya hacia 1725, mientras que en el medio rural había que esperar a la segunda mitad del siglo XVIII. En cualquier caso, la pérdida de fuerza de los gestos habituales en la preparación de la muerte y la tendencia a una laicización del testamento era imparable ${ }^{79}$. Por el contrario, en alguna otra

\footnotetext{
73 Pascua Sánchez, Vivir la muerte en el Cádiz del Setecientos (1675-1801), págs. 99-120.

74 GonzÁlez Lopo, Los comportamientos religiosos en la Galicia del Barroco, págs. 222-284.

75 GonzÁlez Lopo, Los comportamientos religiosos en la Galicia del Barroco, págs. 222-284.

76 García CÁrcel, «La muerte en la Barcelona del Antiguo Régimen», págs. 121-122.

77 Alemán Illán, «Actitudes colectivas ante la muerte en Murcia», págs. 95-120.

78 Rivas Álvarez, Miedo y piedad, pág. 149.

79 Pascua Sánchez, Vivir la muerte en el Cádiz del Setecientos, págs. 247-272.
} 
zona de Cataluña ${ }^{80}$, en Valladolid ${ }^{81}$ o Cantabria ${ }^{82}$ no aparecían signos evidentes de descomposición del modelo. La desafección de la práctica ritual barroca alrededor de la muerte que parecía confirmarse a través de su desaparición de los testamentos peninsulares de algunas zonas fue planteada en la mayoría de los casos por los historiadores españoles lejos de la etiqueta vovelliana de la descristianización, e interpretada como un deseo de vivencia religiosa más auténtica, menos ritual y alejada de una práctica formalista. En general, tampoco los historiadores españoles orientaron su explicación de los cambios en línea con la interpretación de Philippe Ariès o Pierre Chaunu en el sentido de que la desaparición del dispositivo sobre sepultura, entierro y misas pudiera traducirse por un aumento de la confianza del testador en sus deudos y albaceas. Evidentemente la desaparición de estos ritos no tenía porqué situarnos, necesariamente, ante un proceso descristianizador, pero ¿acaso la presencia de los ritos per se era señal inequívoca de un colectivo cristianizado? La historia de la muerte, convertida en una historia sobre gestos, actitudes, sentimientos y valores establecidos, ha hecho caso, entre estos últimos, particularmente de los religiosos, asumiendo que la clericalización de la muerte a lo largo de la Baja Edad Media implicaba de hecho la asunción sin grietas de los mismos. Los gestos se han interpretado como actitudes, desdeñando en general lo que en ellos hay de representación o hábito conveniente; en este sentido no prendió suficientemente la advertencia de Pierre Chaunu sobre la importancia de la muerte como reveladora de un sistema de civilización ${ }^{83}$. Los gestos ante la muerte en la España barroca han sido leídos en términos de un solo valor significante - la religiosidad contrarreformista y su preocupación por la salvación- pero había otros. Multitud de indicios situaban al historiador, en los albores de la Reforma, ante una sociedad escasamente cristianizada y sobre la que el Concilio de Trento verterá su esfuerzo doctrinal y moralizante. Dado el papel que la muerte tiene para el ser humano en general y en el cristianismo en particular, el proceso de conquista post-tridentina se va a ejercer básicamente alrededor de este tema, configurándose un sistema de la muerte que será una de las palancas más poderosas de control ideológico ${ }^{84}$. A comienzos del XIX asistimos a un cambio que cuando menos podemos calificar de desacralizador de la muerte, cuyo significado dependerá, en cualquier caso de la profundidad

80 Lopez Miguel, Actituds col.lectives davant la mort, pág. 60.

81 García Fernández, Los castellanos y la muerte, págs. 216-217.

82 Maruri Villanueva, La burguesía mercantil santanderina, pág. 279.

83 Pierre Chaunu, Historia, ciencia social. La duración, el espacio y el Hombre en la época moderna. Madrid, Encuentro, 1985, pág. 528.

84 Croix, La Bretagne. La vie, la mort, la foi, pág. 892. 
de la creencia y de la vivencia religiosa, lo mismo que su presencia en el testamento barroco no traducía necesariamente la unanimidad y la vitalidad de la fe, sino la socialización de aquellos individuos en un modelo de representación de la muerte que tenía, junto a los significados religiosos, funcionalidades sociales evidentes. La petición de hábito, de sepultura en una capilla bajo una advocación religiosa de popularidad incontestable, de un acompañamiento fúnebre religioso o de misas, nos sitúa ante un modelo sacralizado pero, sobre todo, ante un modelo sancionado positivamente por el colectivo social. Junto a la traducción más directa: deseo de indulgencias, de intercesión de los santos, de consecución de la gloria, en su doble versión, no lo olvidemos, de gloria celestial y fama mundana, hay otra lectura probable e igualmente pertinente de búsqueda de solidaridades terrenas, de ocupación del espacio como símbolo de poder, de prestigio social, o en una versión más general y atmosférica, pero determinante para el ser humano de búsqueda de un antídoto frente al miedo a dejar de ser o al olvido.

De todas formas, en la historiografía española el debate fue primero sobre las temporalidades, o mejor sobre la descomposición del modelo de muerte barroca que sobre la construcción del mismo más tardía ${ }^{85}$ y apenas se trasladó, al menos hasta la década de los 90, al de los espacios, a pesar de su significación en la conformación de lo religioso ${ }^{86}$ y en este ritual en torno a la muerte en cuestión. Más allá de la confirmación de un mapa de dos zonas en la Península, la que reunía a aquellas tierras que mostraban signos evidentes de quiebra del modelo y las que permanecían fieles a él, los análisis sobre el espacio de la muerte barroca fueron tardíos o escasos ${ }^{87}$. No era algo completamente extraño, los historiadores nos hemos incorporado muy tarde al análisis del espacio; imaginándolo más como un todo dado y no tanto como algo a construir y sobre todo como un escenario simbólico. Las grandes tesis de los años 50 y 60 sobre el marco geográfico de mares y océanos siguiendo el modelo braudeliano, detenidas en la construcción física del mismo, solo de soslayo descubrieron las potencialidades que las actividades de los hombres en general ejercían en la construcción del espacio y su proyección mental. En este caso era evidente que el modelo de muerte tenía en el espacio una

85 Martínez GiL, La muerte vivida: muerte y sociedad en Castilla durante la Baja Edad Media, y Jaume Aurell y Julia Pavón, Ante la muerte. Actitudes, espacios y formas en la España medieval, Pamplona, Universidad de Navarra, 2002.

86 Mircea Eliade, Lo sagrado y lo profano, Madrid, Guadarrama, 1981, cap. 1 (edición original de 1956).

87 Domingo GonzÁlez Lopo, «La vivencia de la muerte en las ciudades del Antiguo Régimen: Santiago de los siglos XVII al XIX», en Ramón Villares Paz (coord.), La ciudad y el mundo urbano en la historia de Galicia, A Coruña, Publicaciones de la Universidad de Santiago de Compostela, 1988, págs. 179-198. 
base fundamental para la construcción de un decorado donde tenían lugar un buen número de gestos y ritos y que jugaba con el construyendo, a la par que ocupando y resignificando, en conmemoraciones ordinarias y extraordinarias, un medio destinado a otros usos. La elección de sepultura, decantada hacia las iglesias parroquiales y conventuales, una vez se abandona la inhumación en el cementerio a lo largo de la Baja Edad Media, modifica un espacio que se habita ahora con la muerte y sus representaciones, pero la muerte, a su vez, era habitada y revestida por estos espacios que le aportaban un extra de carga simbólica en este caso, indudablemente religiosa. El templo y cada una de sus partes configuran un cosmos con funciones simbólicas muy definidas y constitutivas del «espacio existencial» — sistema estable de imágenes del medio que rodea al hombre- ${ }^{88}$. Los conventos, además, constituían elementos fundamentales del paisaje urbano, destacando por su monumentalidad y su esplendor pero también por sus funciones sociales y las sepulturas en ellos se contagiarán de estas propiedades. En el paisaje urbano también transcurrirán las exequias, incluyendo el traslado del cadáver a su última morada, con sus paradas o posas y los elementos simbólicos que lo acompañan, en una procesión que representará la sociedad en la que vivía el difunto, doblemente jerarquizada en lo seglar y en lo eclesial. La procesión, rito fundamental de las exequias, a través de su organización y de los elementos que se integraban en ella — clero, frailes, pobres, cofradías, cada uno con sus signos de competencias y de honores- mostraba tanto la prevalencia de los intercesores celestes como los significados sociales en una última representación de «sí» fuertemente teatralizada. Las diferencias ${ }^{89}$ de número — de acompañantes-y de peso social específico — calidades, tamaño de los cirios, número de hachas y paradas, doble de campanas- solo confirmaban el interés generalizado por unas «bellas» exequias, interés en el que coincidieron, artesanos, mercaderes y notables, clérigos y laicos. Aunque cada cual lo aplicara según sus posibles y con las únicas excepciones de aquellos que, porque se podían permitir «lo más» ostentoso, decidían significarse con «lo menos». La difusión del modelo por el espacio urbano evidenciaba la importancia de sus funcionalidades ya

88 Christian Norberg-Schulz, Existencia, Espacio y Arquitectura, Barcelona, Blume, 1975 y Santiago Sebastián López, Espacio y Símbolo, Córdoba, Publicaciones de la Universidad de Córdoba, 1977; Michel Maffesoli, «L'Espace de la socialité», Espaces et Imaginaire, Grenoble, Presses Universitaires de Grenoble, 1979, págs. 15-28. En línea con el planteamiento de Norberg-Schulz de un «espacio existencial», Maffesoli insiste en la dimensión espacial de la sociabilidad.

89 En la Granada del siglo Xvi el estudio de los testamentos de cristianos viejos y los de cristianos nuevos arroja diferencias significativas en este aspecto; tanto en la propia elección del cortejo que, muy presente en los testamentos de los primeros, es menos representativa en los de los segundos, como la austeridad que preside las exequias de estos últimos, García Pedraza, Actitudes ante la muerte, vol. II, págs. 580-583 y 794. 
fuera en Valladolid ${ }^{90}$, Cataluña, Sevilla ${ }^{91}$ o Cádiz ${ }^{92}$. Más ocasionalmente se transformará con los escenarios efímeros que se construirán con motivo de las grandes exequias y funerales de reyes y reinas y príncipes de la Iglesias ${ }^{93}$. Este espacio para la muerte no queda detenido en los momentos inmediatos al óbito, sino que se hace presente también en las conmemoraciones ordinarias y extraordinarias de misas y fiestas perpetuas en memoria del difunto con acompañamiento de parecidos recursos y proyecciones significativas.

A finales del siglo XVIII se produce un cambio de percepción importante respecto al lugar de sepultura. Al menos entre un número significativo de científicos ${ }^{94}$, higienistas ${ }^{95}$, proyectistas y notables, laicos y clérigos, se empieza a difundir la opinión sobre la necesidad de establecer una distancia saludable entre los muertos y los vivos. Esta cautela, general en el mundo romano y traducida en normas sobre la obligatoriedad de enterrar a los muertos en las afueras de las ciudades y villas para evitar problemas de salud, se había abandonado en Occidente a lo largo de la Alta Edad Media, y hacia el siglo XII, los claustros de las parroquias y los cementerios junto a sus muros se habían convertido en el lugar de inhumación general mientras los notables conquistaban el interior de las iglesias situando allí sus sepulturas. La prohibición presente en el derecho canónico no pudo impedir el desarrollo creciente de la conquista, por parte de los muertos, de espacios en el interior de los templos, especialmente de las iglesias conventuales. La fe en la resurrección de los cuerpos asociada al primitivo culto sobre las tumbas de los mártires favoreció el enterramiento en las iglesias que originó problemas notables en los siglos XVII y XVIII. Estos problemas se

90 García Fernández, Los castellanos y la muerte, págs. 216-217.

91 Rivas Álvarez, Miedo y piedad, págs. 139-140

92 Pascua Sánchez, Vivir la muerte en el Cádiz del Setecientos, pág. 164.

93 Juan F. Esteban Lorente, «Mensaje simbólico de las exequias reales realizadas en Zaragoza en la época del Barroco», Seminario de Arte Aragonés, XXXIV (1981), págs. 121-141; Lorenzo Pérez del Campo, «Arquitectura funeraria efímera en Málaga (1550-1650)», Boletín de Arte, 4-5 (1984), págs. 157-178; Victoria Sото Cabra, La ceremonia de la muerte en los Borbones. Un estudio de arquitectura efímera en el barroco español, 1689-1789, 3 vols. Tesis Doctoral, Madrid, UNED (1987); Arita ALLo MANERo, «Origen, desarrollo y significación de las decoraciones fúnebres. La aportación española», Ephialte. Lecturas de Historia del Arte, 1 (1989), págs. 87-104; Javier VARELA, La muerte del rey. El ceremonial funerario de la monarquía española (1500-1885), Madrid, Turner, 1990; Roberto J. López LóPEz, «Exequias reales en Oviedo durante el Antiguo Régimen», Hispania Sacra, 45 (1993), págs. 27-50; Jaime García Bernal, «Las exequias de Felipe II en la Catedral de Sevilla: el juicio de Dios, la Inmolación del Rey y la Salvación del Reino», en Carlos A. González Sánchez (ed.), Sevilla, Felipe II y la Monarquía Hispánica, Sevilla, Ayuntamiento de Sevilla, 1999, págs. 109-130.

94 Enrique GimÉNEz LÓPEZ, «La exhalación de la muerte. La aportación del matemático Benito Bails a la polémica sobre los cementerios en el siglo XVII», Revista de Historia Moderna, 17 (1998-1999), págs. 113-140.

95 Isabel Lobato Franco y Olga López Miguel, «L'espai dels morts: els cementeris i el pensament higienista il.lustrat», Pedralbes (1988), II, págs. 379-385. 
tradujeron, entre otros, en la proliferación de leyendas escabrosas y jocosas sobre los muertos, recogidas en un temprano trabajo de Phillipe Ariés ${ }^{96}$ y en los inicios de una tendencia/política de reestructuración de algunos cementerios superpoblados que afectó a uno de los más simbólicos y famosos de Francia, el cementerio de los Santos Inocentes de París en funcionamiento desde el siglo $\mathrm{XV}^{97}$. En España, sospechas y prudencias sobre los efectos nocivos de la costumbre de enterrar a muertos junto a vivos cuajaron con las disposiciones carolinas sobre enterramientos extramuros en 1787, diez años después de que similares medidas se tomaran en Francia. Una supuesta y generalizada oposición entre la población española a estas disposiciones carolinas sobre enterramientos ${ }^{98}$, fue matizada en una serie de trabajos publicados con motivo de la Conmemoración del Bicentenario de la muerte de Carlos III $^{99}$, investigaciones que evidenciaron una casuística más compleja. En el caso de la Diócesis de Cádiz, el proyecto de cementerios fuera de las ciudades chocó no con la oposición de las ciudades sino con la inexistencia de dotación económica para el proyecto, en ocasiones arropado por las propias autoridades eclesiásticas que venían denunciando los problemas que estaban originando las sepulturas en el interior de las Iglesias. La orden real de 1787 no contemplaba una fuente de financiación concreta para el proyecto de construcción de los nuevos cementerios y cuando las autoridades acudieron al Consejo de Castilla solicitando la creación de nuevos impuestos para sufragarlos no obtuvieron una respuesta afirmativa. Una cierta apatía de las autoridades para llevar a cabo el establecimiento de nuevos cementerios, derivada de las dificultades de financiación se vio favorecida por la inexistencia de plazos temporales para la conclusión del traslado que la propia orden real no fijaba. En cualquier caso, fue la epidemia de fiebre amarilla que se inicia en Cádiz en 1800, que afectará a otros lugares de Andalucía y sacudirá todo el país, la que dará, en muchos casos, el impulso definitivo a la creación de los

96 ARIÈs, «Les miracles des morts», Essais sur l’histoire de la mort, págs. 133-141 y François ZoNABEND, «Les morts et les vivants. Le cimetière de Minot en Chantillonnais», Études Rurales, 52.1(1973), págs. 7-23.

97 Madeleine ForsIL, «Les attitudes devant la mort au xvIIIe siècle. Sépultures et suppressions de sépultures dans le cimetière des Saints Innocents», Revue historique, 512 (1974), págs. 303-330.

98 Peter B. Goldman, «Mitos liberales, mentalidades burguesas e historia social en la lucha en pro de los cementerios municipales», en Alberto Gil Novales (coord.), Homenaje a Noel Salomón. Ilustración española e Independencia de América, Barcelona, Universidad Autónoma de Barcelona, 1979, págs. 81-93.

99 M. ${ }^{a}$ José de la PAScua Sánchez, «El cumplimiento de las disposiciones carolinas sobre enterramientos extramuros en la Diócesis de Cádiz, 1787-1810», en Mariano Peñalver Simó (dir.), IV Encuentros de la Ilustración al Romanticismo, Cádiz, Universidad de Cádiz, 1993, págs. 211-221; Juan L. GaLán CabilLa, «Madrid y los cementerios en el siglo XVIII: el fracaso de una reforma», en Jesús IzQuierdo MarTín et al., Carlos III, Madrid y la Ilustración. Contradicciones de un proyecto reformista, Madrid, 1988, págs. 255-295; Carlos SAGuar Quer, «La aparición de una nueva tipología arquitectónica: el cementerio», El arte en tiempos de Carlos II, Madrid, CSIC, 1989, págs. 207-217. 
nuevos cementerios. Así fue en Cádiz, Sevilla o Córdoba o Málaga. En esta localidad el prelado Molina Lario había denunciado en 1771 la pésima situación de los templos de la ciudad, e impulsó el traslado de los muertos a extramuros; sin embargo, la construcción del nuevo cementerio, aprobada durante la epidemia, quedó inconclusa y no se retomará hasta la epidemia de cólera de mediados del $\mathrm{XIX}^{100}$. En el caso de Barcelona, la construcción del cementerio Vell extramuros, da comienzo en 1775, antes por tanto de la real orden de Carlos III, y a impulsos de las autoridades eclesiásticas —concretamente el obispo Joseph Climent-. $\mathrm{Su}$ inauguración contó con éxito de público, pero en poco tiempo fue abandonado y no se reconstruyó hasta $1836^{101}$. Los nuevos cementerios conservarán las características principales de los antiguos espacios de sepultura: su carácter sagrado, su condición de espacio jerarquizado y su funcionalidad reforzadora de las solidaridades de grupo al tiempo que guardiana de la memoria individual ${ }^{102}$. No obstante, muy pronto la tipología del cementerio formará parte del repertorio arquitectónico y los arquitectos franceses e ingleses comienzan a trabajar en proyectos de cementerios que se deshacen de la herencia medieval y barroca. Estos nuevos proyectos, del que es ejemplo el cementerio francés de Pere Lachaise, inaugurado en 1804, abogan por una estructura que copia el esquema del jardín y servirá como modelo para la transformación de los cementerios parroquiales en Gran Bretaña ${ }^{103}$ y Estados Unidos ${ }^{104}$. Si en el modelo de la muerte barroca, las sepulturas, símbolos a un tiempo de jerarquías sociales y solidaridades terrenas y ultraterrenas, debían constituir una memoria de la muerte como advertencia constante, las de los modernos cementerios decimonónicos respetan las jerarquías y refuerzan la memoria individual al tiempo que forman parte de un conjunto que, construido a modo de imitación del paisaje natural, distraerá a sus visitantes del recuerdo constante de la muerte. En el caso de los nuevos cementerios españoles, sin embargo, los proyectos realizados entre

100 Rosario Camacho Martínez, «Moradas de la muerte en la Málaga contemporánea», en VV. AA., Actas I Encuentro Internacional sobre Cementerios Contemporáneos. Una arquitectura para la muerte, Sevilla, Consejería de Obras Públicas y Transportes, 1991, pág. 38 y José L. Carrillo Martos, Luís García BallesTER, Enfermedad y sociedad en la Málaga de los siglos XVIII y XIX. I La fiebre amarilla (1741-1821), Málaga, Universidad de Málaga, 1980.

101 Isabel Lobato Franco y Olga López Miguel, «L'espai de la mort: L'organització de l'espai als cementeris del segle XVIII. El cementeri Vell de Barcelona», Pedralbes (1988), II, págs. 371-277.

102 M. José de la Pascua Sánchez, "Cuerpo y espacio en el código de gestos de la muerte barroca», en León C. Álvarez Santaló (coord.), Mentalidad e Ideologías en el Antiguo Régimen, Murcia, Universidad de Murcia, 1992, págs. 395-409.

103 James S. CurL, A Celebration of Death. An introduction to some of the buildings, and setting of funerary architecture in the Western European tradition, London, Constable, 1980, en especial los capítulos V y VII.

104 CurL, A Celebration of Death, caps. V y IX. 
1787 y 1845 por arquitectos siguiendo el modelo de la arquitectura neoclásica, aunque será un espacio más ordenado y limpio de algunas de las simbologías de la muerte barroca, no responderá a los nuevos modelos de cementerio jardín franceses e ingleses ${ }^{105}$.

Todas las disposiciones sobre sepulturas, entierros y misas tenían como fundamento, una imaginería del más allá donde primaban otros tiempos y espacios. En este sentido, encuentran fundamento en una gigantesca operación de reestructuración del mundo de ultratumba que tiene lugar en el Occidente cristiano de la Segunda Edad Media ${ }^{106}$. Según Jacques Le Goff, hasta el siglo XII las representaciones del más allá son confusas, si bien domina una representación binaria según la cual aquel queda repartido entre Cielo e Infierno y definido, en cualquier caso, como destino definitivo desde el momento de la muerte. Sin embargo, una nueva concepción del tiempo hija de los cambios económicos que tienen lugar en Occidente desde el siglo XI, y que están asociados a una mayor importancia de los intercambios comerciales y las operaciones financieras, se va a abrir paso. La aplicación de las técnicas contables a la noción de tiempo lo transforma en un valor de mercado, y esta nueva concepción no solo se reflejará en el mundo de las finanzas, sino también en la forma de concebir y planificar ese otro tiempo, el del más allá. En este se abre, entre el Cielo y el Infierno, un tercer espacio-tiempo: El Purgatorio, cuya formulación doctrinal como dogma tiene lugar en el Segundo Concilio de Lyon, en 1274. El Purgatorio se concibe como un espacio-tiempo manipulable desde este mundo a través de las indulgencias y los sufragios; su desarrollo implica el desplazamiento del Juicio Final por un Juicio Particular que decide este destino intermedio. Numerosos trabajos en la historiografía de la muerte, tanto en Francia ${ }^{107}$ como en España ${ }^{108}$, recogen distintos aspectos de esta escatología que sustentaba la representación de la muerte barroca y que se difundió a través de la palabra y las imágenes. Es una Memoria de la Eternidad compuesta por materiales discursivos que versan sobre el destino del alma y del cuerpo: las Artes de morir, los Libros de estados,

105 Alicia GonZÁlez Díaz, «El cementerio español de los siglos XVIII y XIX», Archivo español de Arte, 171-43 (1970), págs. 289-320.

106 Jacques Le Goff, El nacimiento del Purgatorio. Madrid, Taurus, 1985, pág. 13.

107 Le Goff, El nacimiento del Purgatorio, pág. 13; Pierre Chaunu, Memoria de la Eternidad, Madrid, Rialp, 1979; Philippe Arı̀̀s, El hombre ante la muerte, Madrid, Taurus, 1983, págs. 502-503. También, aunque referida a uno de los espacios, la erudita y seductora contribución de uno de los grandes de la historia de la religiosidad y las mentalidades: Jean Delumeau, Historia del paraíso, 3 tomos, Madrid, Taurus, 2004 (edición original de 1991).

108 Respecto a la historiografía española merece destacarse, por la incorporación de la escatología musulmana, el capítulo que le dedica Amalia García Pedraza, Actitudes ante la muerte en la Granada del siglo XVI, Granada, Universidad de Granada, 1002, págs. 147-180. 
y la literatura moral y religiosa en general, pero también por pinturas y esculturas. Entre las primeras, la muerte y su memoria fue la protagonista esencial de un tipo de bodegón de gran difusión en la pintura barroca española, la Vanitas con maestros como el sevillano Juan de Valdés Leal o el vallisoletano Antonio de Pereda como representantes destacados. Las segundas están, asimismo, bien representadas en los numerosos altares de ánimas que pueblan las iglesias barrocas y sobre cuya importancia en la difusión del dogma del Purgatorio alertó tempranamente Michel Vovelle ${ }^{109}$. Aunque varias de las investigaciones sobre actitudes ante la muerte en España analizaron la devoción a las ánimas del Purgatorio ${ }^{110}$, una devoción en franca decadencia en algunas zonas como Sevilla ${ }^{111}$, existen algunos trabajos específicos sobre las mismas ${ }^{112}$.

En esta escenografía del más allá, el cambio más significativo viene dado por el paulatino desplazamiento del destino colectivo (Juicio Final) por el destino individual (Juicio Particular). Desde el siglo Xvı, la idea de «Fama» está alejándose de la idea de «Inmortalidad» y asociándose a las realizaciones civiles — virtudes caballerescas, erudición humanística- y no tanto a la santidad $^{113}$. Indudablemente esta secularización de la idea de la gloria es un proceso lento, pero enormemente significativo. Acompañado de otras evoluciones como la importancia que cobra el destino propio en el Juicio individual que se impone, estos cambios nos sitúan ante una mayor relevancia de la conciencia de sí y de la memoria individual en la concepción de la muerte ${ }^{114}$. En esta perspectiva

109 Gaby et Michel Vovelle, Vision de la mort et de l'au-delà en Provence, págs. 13-17.

110 GonZález Lopo, Los comportamientos religiosos en la Galicia, págs. 475-624.

111 Rivas Álvarez, Miedo y piedad, págs. 104-105.

112 Miguel L. López-Guadalupe Muñoz, «Imágenes del más allá. Culto e iconografía de las Ánimas en la Granada moderna», en Antonio Luís Cortés Peña (coord.), Poder civil, Iglesia y Sociedad la Edad Moderna, Granada, Universidad, 1999; Antonio Cantero Muñoz, «Religiosidad popular y Semana Santa en Doña Mencía: la devoción a las Ánimas benditas del Purgatorio durante el Antiguo Régimen, 1492-1837», El Bermejino, 269-272 (2002), sin paginar, entre otros.

113 Ariès, Essais sur L'histoire de la mort, pág. 92. Jacob BurскнаRDT había reflexionado sobre estos aspectos, señalando que el Renacimiento aportó la idea de fama, vinculada al recuerdo de las propias hazañas y virtudes y como memoria de sí, así como el descubrimiento del hombre como alma. Burckhardt había atribuido el renovado clima artístico e intelectual de la época a la aparición de un nuevo tipo de hombre. Un hombre que a diferencia de sus antepasados medievales, que solo se concebían como miembros de una familia, corporación, estamento o grupo, se caracterizará por una nueva conciencia de sí mismo como agente autónomo, dotado de personalidad independiente y psicológicamente compleja, en La cultura del Renacimiento en Italia, Barcelona, Ediciones Zeus, 1968 (1. ${ }^{a}$ ed. antes de 1897), págs, 134 y sigs. También Jean Delumeau dedica unas palabras a la confusión entre las dos glorias en el siglo xvi, Historia del Paraíso, vol. III, págs. 553-556.

114 Gurevich señala que, si bien a finales de la Edad Media la idea del Juicio Final no ha desaparecido del todo, en los relatos sobre apariciones de muertos y visitas al otro mundo el lado individualizante del aprendizaje de la muerte y el castigo están en primer plano (Aaron Gurevich «Au Moyen Age: conscience individuelle et image de l'Au-Delà», Annales ESC (1982), 2, págs. 255-266). 
pienso que las investigaciones sobre actitudes y vivencias de la muerte, más que concluir, han quedado interrumpidas e inacabadas.

La producción historiográfica sobre la muerte, a pesar de las llamadas de atención que venían produciéndose desde los años 70 y 80 sobre los cambios producidos en la forma de vivir la muerte en las sociedades occidentales, marcados por una deshumanización y comercialización creciente $^{115}$, y por la pérdida de la dimensión más personal de la misma, es decir, la individual ${ }^{116}$, situaron el énfasis en los aspectos de la cultura de la muerte que el hombre histórico había compartido con sus contemporáneos. Así los gestos comunes del ritual de la muerte católica, uno a uno, fueron interrogados, aunque siempre desde la perspectiva de la serie en la que estaban insertos de forma sistémica respondiendo a un modelo clericalizado de muerte procedente de la Plena Edad Media y que se había generalizado en la Europa de la Contrarreforma. Estas investigaciones de los años 80 dejaron al margen la perspectiva biográfica y una visión del testamento como documento del yo que a mi parecer es fundamental. El testamento aparece en la época como una de las variedades de escrituras últimas más difundida — recuérdense los porcentajes medios de práctica testamentaria, en general superiores al $30 \%$ de la población adulta- Sin duda hubo otras escrituras últimas que fueron familiares a los hombres y mujeres de la época y cuyo uso fue también frecuente (epigramas, epitafios, túmulos, templetes ${ }^{117}$ ), además de la enorme cantidad de sermones fúnebres, descripciones de pompa funeral, artes de morir y toda una abundante literatura espiritual y moral que tenía el propósito general de familiarizar y guiar a los creyentes por el camino del tránsito. Pero testamentos, romances de pecador arrepentido, memorias testamentarias, cartas de despedida, entre otras, constituyen dentro del grupo de escrituras últimas una fuente inagotable para los historiadores. Los preámbulos de los testamentos, los epigramas que adornan algunas publicaciones de honras ilustres, los grabados que acompañan a los libros espirituales

115 Jessica Mitford, The American Way of Death, New York: Simon and Schuster, 1963, subrayaba cómo, en los últimos años, las ceremonias de la muerte se habían convertido, a partir del núcleo del party funeral o moderno funeral americano, en una especie de broma macabra; algo grotesco producto de una industria funeral que había adaptado para él el lenguaje familiar en la Av. Madison para todo tipo de productos. La muerte se había convertido en un momento más para consumir determinados productos.

116 Para el sociólogo Jean Ziegler nada determina más profundamente una civilización que el lugar que ella da a la muerte. La sociedad moderna capitalista rechaza la muerte y niega un estatuto a sus difuntos; como contrapartida, la muerte aparece como neurosis o como locura en un hombre que privado de su finitud -de la conciencia de su finitud- deja de ser un sujeto activo de su historia. Porque es la muerte la que transforma la vida en historia consciente, la que instaura la libertad. Liberar la muerte y reintegrarla al ser social es fundamental para cambiar nuestra vida (Jean Ziegler, Les vivants el la mort, París, Éditions du Seuil, 1975).

117 Armando Petruchi, Escrituras últimas, Ideología de la muerte y estrategias de lo escrito en el mundo occidental, Buenos Aires, Ediciones Ampersand, 2013 (edición original de 1986). 
sobre las temporalidades, las Vanitas que iluminan en claroscuro los cuadros barrocos, contienen mensajes muy similares anclados en una tradición religiosa que indudablemente se halla solapada con una cultura clásica que le sirve como escenario de fondo. Algunas obras de referencia ilustran sobre el significado y la procedencia de este discurso, de la misma forma que ayudaban a escritores, moralistas y artistas (pintores, grabadores, escultures) a transitar por el paisaje de los símbolos y de mensajes codificados desde una perspectiva religiosa e ideológica muy hermanadas. En su libro de Emblemas morales $(1610)^{118}$, Covarrubias se adentra por algunos de ellos, acompañando los emblemas con un comentario clarificador síntesis de los tópicos de procedencia erudita y clerical con que en la época se representa la muerte. Pero todas estas fuentes pueden ser analizadas al servicio de una perspectiva individual con potencialidad para ofrecer lecturas y significados no explorados y en franca correspondencia con la evolución de la cosmografía del más allá. La asociación muerte/juicio, especialmente en su versión de Juicio individual, deviene, desde el Concilio de Trento por el énfasis de las obras sin las que la fe no es nada, en sustento del dispositivo testamentario que acompaña a la obligada protestación de fe del Preámbulo del testamento, como su corolario «natural». Este hecho proporciona al documento un carácter de acta de confesión y rendición de cuentas que comparte con el resto de la escritura autobiográfica, aspecto este en el que insistiré más adelante.

Catecismo de la iconografía contrarreformista, la obra de Covarrubias permite adentrarse por el mundo de los códigos simbólicos tan importante en la cultura del hombre barroco. Estos, como síntesis de mensajes clarificados, limpios de polvo y paja, también repetidos hasta la saciedad y, desde luego, ortodoxos ponen a disposición del fiel las palabras y los gestos con los que canalizar la angustia ante la muerte, la amenaza del fin. Pero, por debajo de este ropaje religioso que contagia palabras y gestos depositados en las escrituras últimas, palpita la angustia antropológica de la muerte, y esta nos devuelve una imagen individual aparentemente oculta en la cultura colectiva. Escribe Edgar Morin que la muerte constituye una triple constante antropológica, relacionando tres aspectos fundamentales para el ser humano, a saber, la conciencia de la muerte, el horror por la pérdida de la individualidad y la creencia en la inmortalidad. El ser humano se resiste a dejar de ser y aspira a conservar su personalidad a través de la creencia en la inmortalidad. En una inmortalidad sacra — la gloria, el más allá gratificante—o laica — la idea de fama— ${ }^{119}$. Esta ansia por permane-

118 Sebastián de Covarrubias, Emblemas morales, Madrid, Imprenta de Luís Sánchez, 1610. (Manejamos un ejemplar de la Library of the University of Illinois, Colección Raros y Especiales (096.1, C837e), disponible en red).

119 Edgar Morin, El hombre y la muerte, Barcelona, Kairós, 1999, págs. 32-37. 
cer encuentra cauce en la idea de inmortalidad común en muchas religiones que la contemplan de diferentes maneras pero que no siendo privativa de la religión cristiana halla en ella una especial trascendencia, reforzada por la idea de una muerte que da acceso a la verdadera vida. El discurso que soporta el testamento, como documento en el que el testador dialoga con una muerte próxima, real o simbólica, da cuenta de los códigos, las palabras y los gestos que pertenecen a esta cultura de la muerte compartida por la mayoría. En ese sentido su estudio a través del tratamiento cuantitativo de series de testamentos otorgados en estos siglos se reveló acertado y eficaz al proporcionar en el orden de magnitud de diferentes prácticas alrededor de la muerte —elección de mortaja, sepultura, acompañamiento funeral, misas y otras disposiciones piadosas - la implantación del modelo de muerte barroca. Pero no solo: el seguimiento de la discontinuidad de los gestos y las temporalidades de los mismos permitió el seguimiento de la fortaleza del modelo y las grietas que se abrían en él a lo largo del siglo XVIII. Sin embargo las investigaciones de los 80 y 90, en general, pasaron por alto que parte de la angustia y de los miedos que las mujeres y los hombres de la época sintieron ante su muerte no estaban en su totalidad inducidas por la cultura de la muerte católica, sino que provenía de las propias circunstancias personales, del contexto familiar, de las dependencias emocionales, y, en este sentido, el tratamiento del testamento como documento personal es fundamental, revelándose como más adecuado y productivo. El testamento, como escritura de la muerte, sirve para afirmar, legar o construir un más allá en el que los individuos pueden mantenerse «presentes» en una nueva individualidad significada y es que, aunque acusado de estereotipado ofrece en muchas de sus cláusulas, una prueba imparable de individualismo ${ }^{120}$. Como expresión de las muchas paradojas que significan la muerte, también en los aspectos de conciencia del final, voluntad de balance y necesidad de permanecer en la memoria de los otros, los testamentos están necesitados de estudio, de un estudio que explore la muerte a partir de la conciencia de la identidad y la singularidad del individuo, desde una perspectiva autobiográfica.

120 Aaron Gurevich, Los orígenes del individualismo europeo, Barcelona, Crítica, 1997, págs. 91-98. 